\title{
THE RESURRECTION OF REGISTRATION OF TITLE
}

\author{
Percy BordWELL*
}

I $\mathrm{N}$ A period of readjustment, old ideas which have lost their vogue are likely again to be advocated along with ideas whose main attraction is their novelty. In the closing years of the nineteenth century and the first two decades of the twentieth there was considerable agitation in the United States for registration of title to land. In the prosperous twenties, reform was quiescent, and with it the reform of land transfer. But with the collapse of three of the four large New York title insurance corporations as an incident of the great depression, title insurance again came to public attention, and title registration was urged as something better. As a consequence the ghost of title registration again walks in that state.

In normal times reform is under a grave disadvantage. Vested interests are entrenched while the main strength of the reform is in the egoism of the reformer. In times of change the advantage is perhaps the other way. But in either case attention is likely to be centered on the special interest of the existing order or on the personality of the reformer rather than on the merits of the case. The merits of either side are likely to be assumed and attention directed at discrediting the other side. So at any rate has it been with registration of title to land. Its advocates have largely assumed its manifest superiority over prevalent systems of recording and have harped on the self-interest of the English solicitors, or in this country on that of the abstracters or the title insurance companies. Self-interest, however, is not always on one side. There is no more insidious self-interest than that of a government department desiring to expand. Such a department exists in England in the Land Registry, the head of which, the Chief Land Registrar, is appointed by the Chancellor and has his powerful backing. In the United States it is the titlemen and especially the title insurance companies that are accused of self-interest. Their self-interest is manifest. But the failure of past attempts at registration of title cannot altogether be laid to them. Their influence was not

* Professor of Law, State University of Iowa.

× The Land Registry was created in 1862 by Lord Westbury's Land Registry Act, 25 \& 26 Vict., c. 53 . 
sufficient to block legislation in many states ${ }^{2}$ nor, it is believed, does it account for the ineffectiveness of most of that legislation. ${ }^{3}$ That ineffectiveness is an outstanding fact and should be examined dispassionately for any light that it may throw on the merits of the case. Similar legislation was long ineffective in England. Without holding any brief for the English, one cannot help being struck by the fact that they learn the lesson of ineffective legislation better than we do.

Registration of title to land is commonly associated in the United States with one type of such registration, the Torrens System. The name, "Torrens System," like the name "Townsend Plan," is known to countless persons who have only the haziest idea of the system or plan for which the name stands. The name itself, therefore, has been of the greatest advertising value. It has lent itself to propaganda and the formation of leagues ${ }^{4}$ or clubs. It has helped make the movement for the registration of title seem a cause, and the system itself a panacea from which the most beneficent results may be expected. By a simple change in land transfer, land is to become liquid and credits established. Not all who advocate registration of title to land would probably claim all this, but what else can be meant by those who urge that land should be as easily transferable as a ship or a share of stock or an automobile?s Certainly they are at the opposite pole from the advocates of that other panacea, the Single Tax, who would deny not only all resemblance between chattels and land but also the private ownership of land.

3 Powell, Registration of the Title to Land in the State of New York 54-6 (1938) states that exclusive of New York there are twenty-one subdivisions of the United States which have had constitutional or legislative provisions dealing with the registration of title to land but that of these only seven have made any substantial use of the system. To the fourteen where the use has not been substantial should be added New York. Ibid., at 53. Of the seven where the use has been substantial, two are outlying possessions, Hawaii and the Philippines, and five are states, California, Illinois, Massachusetts, Minnesota, and Ohio.

3 The tendency to explain away the failure of title registration in these states by attributing it to the malign influence of the titlemen is seen even in McDougal \& Brabner-Smith, Land Title Transfer: A Regression, 48 Yale I. J. Ir46-8 (1939) and in Fairchild \& Springer, A Criticism of Powell's Book, 24 Corn. L. Q. 557, 573-4 (1939). This is on the same level as the charge that our entry into World War I was due to profiteers. The Satanic interpretation of history is all too common today but it does not get us anywhere.

4 Thus, Fairchild, co-author of the article in 24 Corn. L. Q. 557 (I939), is President of the New York Torrens Title League.

${ }^{5}$ See McDougal \& Brabner-Smith, op. cit. supra note 3, at I1 26; Fairchild \& Springer, op. cit. supra note 3 , at 576-7. This slogan goes back to the early history of the fight for title registration in England. Both the slogan and much of the argument for title registration in the United States have been taken from the English experience without due regard for their application here. 
However, the fact that advocates of the Torrens System have claimed for it advantages that are beyond all reason should not blind us to any merits it may have. If it cannot make land as liquid as a share of stock but on the other hand promises better results than the system of land transfer we now have, it is at any rate worth considering. In looking into the matter, the more we get away from names, whether the name be the Torrens System or Registration of Title or Registration of Deeds, the better. Without the prejudice and preconceptions that go with names we can discuss change in the mechanism of land transfer in the same temper in which we would consider alteration of the rules of the road. ${ }^{6}$ No great moral issue is involved, but simple matters, such as indexing and quieting and insuring titles. Go beyond these and the changes become more radical, and may even involve revamping of the general property law. Such a consequence may be an argument in favor of such changes, but, on the other hand, if we do not desire such general modification of property law, this may weigh heavily against the advantages, such as cheapness and quickness, which it is claimed ensue from governmental transfers with assured title. In any case the matter is one of balancing conveniences after as much as possible has been learned from experience.

Any advocate of title registration would do well to mark the struggle for title registration in England, for a by-product of that struggle is the most outstanding feat of title registration-the scrapping of the largest part of that most characteristic segment of English real property law, the historic law of estates.

Such far-reaching consequences would indicate that something more than a simple change in the method of land transfer lay behind the struggle. Such, indeed, was the case. The proponents of free trade in England a hundred years ago sought not only repeal of the corn laws but free trade in land as well. ${ }^{7}$ At that time English land was commonly settled land. This meant that land was tied up in families, that there were classes, and that there was a tendency toward perpetuation of government by and in the interests of landowners. On the other hand, free trade in land resulted in commercialization of land, the putting of land on a par with chattels,

${ }^{6}$ This point is well made by McDougal \& Brabner-Smith, op. cit. supra note 3 , when they state: "Factually, the Torrens system is just a different, and more efficient, way of keeping the public records" (ibid., n. 5), when they take up the steps in land transfer without the use of the familiar phraseology (ibid., at Ir29-30) and finally when they decry the sharp antithesis between "recordation" and "registration" (ibid, at II49). Names are useful tools but too easily run into conceptualism.

7 For a most illuminating account of land law reform in England and its relation to the movement for free trade, see Dicey, The Paradox of the Land Law, 2I L. Q. Rev. 22I, 227 (rgo5). 
the breaking of the hold of the landed classes, and the greater utilization of land. The register of title was significant at least as a symbol of free trade in land. ${ }^{8}$ If, as was claimed, the register could make parcels of land as freely transferable as chattels, free trade in land would be an accomplished fact. In I862 the Land Register was adopted but it proved a great disappointment. After a generation of trial, the number of registrations was still negligible, ${ }^{9}$ and this despite the fact that by Lord Cairn's Land Transfer Act of $1875^{\text {To }}$ the registration of possessory titles was made "easy and practical."'

The evidence became convincing that unless registration of title were made compulsory, it would amount to very little. ${ }^{.2}$ Accordingly in 1899 , registration was made compulsory on sale in four parishes of the County of London, and by I9O2 compulsory registration was extended to the entire county..$^{13}$ However, at least 94 per cent of the applications for first registration in the County of London from I899 to I 909 proved to be for possessory titles, ${ }^{14}$ which type of registration had few of the advantages claimed for the ideal system. ${ }^{x}$ A search of the title prior to the date of registration was still necessary on each transfer and registration did not make the title good.

Despite the limited success of title registration until this time, its advocates still had faith in $i^{t^{16}}$ and the fight for its extension went on. The World War caused a suspension of law reform, but post-war psychology was all in its favor and was also favorable to compromise. Between I926 and 1936 there was a period of truce, during which no forced extension of compulsory registration was to be made. ${ }^{17}$ In the year following the truce,

8 Ibid. at 222, 227; Dicey, Law and Opinion in England 202 (I9I7).

9 In 1895 less than one-third of one per cent of the land of England and Wales was on the Register. Second and Final Report of the Royal Commission on the Land Transfer Acts, Ig08II, p. Ix.

${ }^{10} 38 \& 39$ Vict. c. 87 ( 1875$)$.

Ix Second and Final Report, op. cit. supra note 9 , at 9.

12 Second and Final Report, op. cit. supra note 9, at $\mathrm{rr}$.

${ }_{13}$ Second and Final Report, op. cit. supra note 9, at $2 \mathrm{r}$.

${ }_{4} 4$ Second and Final Report, op. cit. supra note 9, at 26 . As many as 56 per cent of the titles were still not guaranteed in I920. In the same year, $6 \mathrm{I}$ per cent of the titles in non-compulsory areas were not guaranteed. Report of the Chief Land Registrar for $193^{8-9}$, at 7. In I938, under the influence of the Property Acts of $x_{925}$, non-guaranteed titles had fallen to one per cent in compulsory areas and to three per cent in non-compulsory areas. Ibid.

15 Second and Final Report, op. cit. supra note 9, at 30 .

${ }^{16}$ The Royal Commission on the Land Transfer Acts, I908-II, came to the conclusion that "the principle of such a Registry is, in our opinion, sound and valuable." Ibid., at 25.

27 Land Registration Act 1925, I5 Geo. V, c. 2I, § 120 (2). 
extension was not to be imposed on more than a single county ${ }^{\mathrm{x}}$ and in any case six months' notice was to be given of the proposed extension with provision for an inquiry as to its desirability..$^{19}$

The truce was incident to vast changes in the land law and was agreed upon to allow these to work themselves out. ${ }^{20}$ The peculiar triumph of land registration was that it had a profound influence on these changes. ${ }^{2 x}$ They were made with the view of fitting settled land for the Register and at the same time of gaining for unregistered land many of the advantages of registered land without resort to the Register. The new system of private conveyancing, it was said at the time,

is, in fact, a "loose-leaf" registration of title. The document showing who is the person for the time being able to deal with the legal estate in the land, and, where there is a settlement, who are the trustees, corresponds to the entries in the Property and Proprietorship Registers, and any instruments creating mortgages correspond to the entries in the Charges Register. These should be as simple as the entries in the Registers, but instead of being a book or file at the Registry, they are in the possession of the owner or mortgagee, and pass on a conveyance of the property.22

Advocates of title registration urge that it does much more than this but that is beside the point here. To have been an important factor in reducing legal estates in land to the fee simple absolute in possession and the term for years absolute, ${ }^{23}$ whether this be for better or for worse, is in itself no mean accomplishment.

The ten years' truce seems to have reduced the rancor over title registration. During this period, the provincial towns of Eastbourne and Hastings voluntarily accepted the compulsory system, the former in I926, the latter in I929. In I937, the system was extended to Middlesex. ${ }^{24}$ Croydon was added in $1939,{ }^{25}$ and Surrey has been given notice of such a change for $1940 .^{26}$ All of Middlesex and Croyden and parts of Surrey are within

${ }^{18}$ Ibid., § 122 (xi).

x9 Ibid., § 122 (i) (iii).

${ }^{20}$ See Lightwood, The Future of Registration of Title, 75 L.J. 3 (1933).

${ }^{2 x}$ The interrelation of "facility of transfer and simplification of title" was apparent from the first proposal of the Register in 1857 (see Second and Final Report, op. cit. supra note 9 , at 49) and became even more apparent as time went on. The Royal Commission of rgo8-xI said: "Experience of the working of the registration system shows, in our opinion, that it would be greatly facilitated by improvements in the law of Real Property." Ibid. They then discussed various proposals which were the groundwork for the reforms of r925. Ibid., at 49-53.

${ }^{22} 64$ Solicitors' J. 747 (r920); see Lightwood, Registration of Title, 69 L.J. 4r7 (r930).

${ }^{23} \mathrm{Law}$ of Property Act I925, I5 Geo. V, c. 20, \& I (I). See 85 L.J. 4 (1938).

24 Report of Chief Land Registrar for 1938-9, at 5 .

${ }_{25}$ Ibid., at $3 ; 82$ Solicitors' J. ro55 (1938).

${ }^{26}$ Land Registration: Compulsory Areas, 82 Solicitors' J. 67x (1938). 
the Metropolitan police area, or "Greater London." Kent and Essex would seem next in line both because their position is similar to that of Surrey and because of the relatively large number of voluntary registrations. ${ }^{27}$ For the duration of the War, however, any extensions seem unlikely. The absence of the rancor that was formerly noticeable is seen in the reply of the council of the Law Society, the solicitors' association, to the notice of the proposed extension of compulsory registration to Croydon and Surrey: "The council replied that their policy was not to obstruct the extension of land registration in areas where it is proved to be desired, but rather to do all they could to assist in making the working of such extension harmonious and efficient." However, they added: "They are assured by their provincial representatives that many areas in the country are not ready for the extension of registration. ${ }^{\prime \mathbf{2}_{8}}$ In any event, the permanency of title registration in the vicinity of London seems assured. Its gradual extension elsewhere seems to be assumed.29 But for the greater part of England it is a prospect rather than a reality. A less able Chief Land Registrar, a let-down in the enthusiasm incident to the launching of a new venture, some untoward incident, the disinclination of the rest of England to follow London-any or all of these, or some other factor, may mean that the movement started in London will prove to be but a ripple that will soon wear itself out. Thus, in 1938 , the finances of title registration showed a sudden reversal. An estimated surplus of $£_{44}, 000$ became a deficit of $£_{I I, \infty}, \infty$. This was due to a drop in land values. ${ }^{30}$ Perhaps the incident was not very important but nevertheless some of the glow was taken out of the picture. ${ }^{3 x}$

English experience in the extension of title registration suggests several conclusions. In the first place, without compulsory registration title registration was of small importance. From I862, when the Register was first instituted, until December 3I, I909, there had been only 2,042 first

${ }_{27}$ In $x 938,18.7$ per cent of non-compulsory registrations were in Kent and 15.2 per cent in Essex. From there it dropped to 7.5 per cent in Sussex with the rest of England, except Surrey, scattering. Report of the Chief Land Registrar for 1938-9, at 8.

${ }^{28}$ I86 I. T. 34 (I938).

${ }^{29}$ Lord Tomlin's Land RegistrationCommittee of r93o felt it to be outside the scope of their authority to consider the advisability of extending the area of compulsory registration but they were very complimentary as to the way in which the system as then constituted was working and the whole drift of the report was toward the general adoption of the system throughout England and Wales. Mr. Lightwood considered the report "tendencious" in that respect. 69 L. J. 347 (1930). See also 2 Conveyancer and Property Lawyer (N.S.) 295 (I938).

30 Report of the Chief Land Registrar for $1938-9$, at 2.

${ }^{31}$ See Lightwood, 87 L.J. 423 (I939). 
registrations in England and Wales in voluntary areas. ${ }^{32}$ The pace had quickened to $I, 035$ in the calendar year I92I, had slowed up for four years and then gone ahead again in 1926 with the Property Acts of 1925 in effect. The peak was reached in 1936 with 4,915 first registrations. Then the inclusion of Middlesex in the compulsory area caused a fallingoff in voluntary registrations. ${ }^{33}$ In I938 there were some I,O9I voluntary first registrations in areas not in the immediate vicinity of London. ${ }^{34}$ These must have been scattering as apparently no county in this group had as many as 7.5 per cent ${ }^{35}$ of the total first registrations, or 265 , with an average per county ${ }^{36}$ of less than 24 , or about the number of actions to quiet title which one might expect in a single year in an average-sized county in the Middle West of the United States. ${ }^{37}$ The Law of Property Acts of $x 925$ greatly aided title registration so that the showing for voluntary registration since has been better than it was in the Report of the Royal Commission in $19 \mathrm{II}^{3^{8}}$ but there has been no rush to the Register, nor, apparently, is there likely to be. The example of Eastbourne in I926 and of Hastings in 1929 in asking to become compulsory areas ${ }^{39}$ has not been followed. The general adoption of the Register as a means of transfer would seem to depend as much as ever on the extension of compulsory areas on the initiative of the Privy Council. In the meantime, the mainstay of registration in non-compulsory areas has been its success in compulsory areas. ${ }^{40}$

In the second place, the register appears to be unsuitable for the multiple common law estates. If the common law doctrine of estates is an anachronism, we should be as ready to discard it as we would an old shoe. But is it an anachronism? Both in England and the United States there has long been a movement to assimilate the law of real property to that of personal property. The recent abolition of copyhold tenure in England and the abolition of feudal incidents there have made feudal tenure in England merely nominal, and it has never been anything but a shadow, if

${ }^{32}$ Second and Final Report, op. cit. supra note 9, at 26.

33 Report of the Chief Land Registrar for $1938-9$, at 5 .

34 There were $3,66 \mathrm{I}$ first registrations in non-compulsory areas (ibid.) and 29.8 per cent of these were from counties other than Surrey, Essex, Kent and Sussex. Ibid., at 8.

3s This figure is given for Sussex. Ibid.

${ }^{36}$ This is on the basis of the exclusion of six counties, London, Middlesex, Surrey, Essex, Kent, and Sussex, from a total of fifty-two in England and Wales.

37 In 1938 there were eighteen such actions filed in Johnson County, Iowa, and this was said to represent a decline.

${ }^{8}$ Note 9 supra.

39 P. 474 supra. $\quad 4^{\circ}$ See Report of the Chief Land Registrar for 1938-9, at 2. 
that, in the United States since the Revolution. The same tendency is exemplified in England and in many of the United States by assimilation of the law of testate and intestate succession to land to that of personalty. But in the law of estates and especially future interests, the tendency has been the other way. Although the law of estates has no technical application to personalty, when it comes to matters that count, it is treated as though it had. There is good reason for this result. Were the law of estates and future interests abolished, we should be obliged to start all over again with ideas based on the crude notions of property in chattels, or with something like the civil law notion of dominium, or to throw the whole into equity as has been done in England. No one of these three courses seems desirable. Notions of property in chattels have been of the crudest except insofar as these have been influenced by the law of real property. It is no accident that we do not care to substitute for our own the far less developed civil law conceptions of future interests. It is unnecessary to make all future interests in land equitable because the need for a trustee is not the same in the case of land as in the case of chattels, and because we lack the English problem of the family settlement. To the writer, the law of estates and future interests does not seem an anachronism, much as it needs to be clarified in the United States. If registration of title does mean scrapping the law of estates and future interests, it would seem a minor matter whether that scrapping occurs as a preliminary to the Register or as a consequence thereof. The important thing to bear in mind is that the logic of registration of title is a revolution in our land law. More is involved than mere changes in methods of transfer.

The English experience presents numerous other lessons for both advocates and opponents of title registration. One of these is that compulsory registration does not mean that all land need be brought immediately on the register. Any such procedure would suggest the haste and confusion, say, of the NRA, or the high-handedness of the great military empires of other days or of the authoritarian states of today. Under the English scheme, registration, though compulsory, need not take place until there is a sale..$^{4}$ In this way the haste, confusion, and arbitrariness of a sudden shift of all land to the Register is avoided. At the same time this avoids the anomaly of two active registers with two systems of land transfer competing, if not in perpetuity, at least for an indefinite period. Thus when Middlesex accepted the compulsory system, the old register of deeds was closed. ${ }^{42}$ The voluntary sys-

41 Land Registration Act 1925, I5 Geo. V, c. 21, § 120 (i).

42 Report of the Chief Land Registrar for r938-9, p. 9. This was in pursuance to Land Registration Act I936, 26 Geo. V and I Edw. VIII, c. 26, $\$ 2$. 
tem was based on the liberalism of the last century. But the right of the owner of land to choose between an alphabetical index under the prevailing system and a tract index under registration hardly seems to be of the essence of liberty.

The English experience suggests still other lessons. The higher cost of initial registrations as compared with that of subsequent transfers ${ }^{43}$ should be noted. It is also worthy of note that although only a "good holding title" and not a "marketable title" is necessary for registration as an "absolute title" 44 yet the antecedent claims that have thus been overridden seem to have been negligible. 45 This is some indication that courts have been too. fussy about marketable title.

In the controversy that has arisen over the failure of the New York title insurance companies there has been a tendency on the one hand to discount the English experience with title registration because of the difference in conditions ${ }^{46}$ or on the other hand to overstate the relevance of that experience and to deny the very obvious differences in conditions that do exist.47

As already pointed out there would seem to be much that can be learned from the English experience that is relevant to our own. On the other hand even though title registration should finally prevail throughout England that would not be much of an argument for its adoption in the United States. As has been pointed out, title registration in England was a symbol and a tool in the fight for the free alienability of land. In the United States land is freely alienable. In the greater part of England today conveyancing is still secret except insofar as this has been changed by the Land Charges Act of $1925 . .^{48}$ As long ago as the Statute of Uses this secrecy was denounced and yet it has continued, incredible as this may seem. But in the United States public transfers have existed from the first. Had we no system of public transfers, it would behoove us to select one, and

${ }^{43}$ See Powell op. cit. supra note 2 , at 285 . The difference is likely to be greater in noncompulsory than in compulsory areas. In view of the heavy loss in non-compulsory areas during $1938-9$ the Chief Land Registrar reports that "the time may have come when the permanent differences between the working of land registration in compulsory and non-compulsory areas should be reflected in the Fee Order in operation in the respective areas." Report of the Chief Land Registrar for r938-9, at 3 .

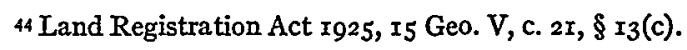

${ }_{45}$ For the relatively small losses from the insurance fund, see Powell, op. cit. supra note 2 , at 285 .

${ }^{4} \mathrm{Ibid}$., at 56 .

${ }_{47} \mathrm{McD}$ ougal \& Brabner-Smith, op. cit. supra note 3 , at II35-8; Fairchild \& Springer, op. cit. supra note 3 , at $5^{6} 5^{-73}$.

$4^{8}$ I5 Geo. V, c. 22 (I925). 
certainly a case for title registration might be made. But we have such a system, and the question with us is whether we shall supplant it. Under these circumstances the case for title registration must be much stronger. In the field of politics, the parliamentary form of government would seem more democratic than the presidential. If we were working in a vacuum we might adopt it. But we are not, and the relative merits of the two systems are academic.

Other differences between the English situation and our own have at times been emphasized: the existence in England of a trained civil service as compared with the prevalence of untrained politicians in public offices in the United States, the freedom of England from a written constitution, and our doctrine of separation of powers. Recent changes in constitutional theory have perhaps rendered our constitutions a less serious obstacle to legislative change than they were a generation ago, but they still are a realistic factor. The infiltration of much new blood into the civil service would seem rather spasmodic and by no means to involve a purge of politics from the civil service. Constitutional difficulties no doubt tend to promote delay, red tape, and greater expense, while an untrained civil service tends to inefficiency and waste. These factors are perhaps not decisive but their weight cannot be ignored.

Finally the problem of statutory reform in the United States is very different from that in England because of the federal character of our government. As it stands, the common law has some coherence and uniformity throughout the country. The recording acts date back to Colonial times and have become as substantially a part of our common law as are the early English statutes. They are an integrated part of the American land law. If the land law were federal, we could make a more or less revolutionary change in it by congressional act and still have an American land law. The same kind of change by a state statute would merely add that state to Louisiana as a peculiar jurisdiction. Instead of progress toward uniformity the result is likely to be increased divergence and local law. An outstanding example of this is the New York Revised Statutes of I829. They have been compared to the English property legislation of 1925.49 The comparison is just one hundred years out of date. The Revised Statutes of 1829 are comparable to the legislation recommended by the English Real Property Commissioners of I829-33 and sprang from the same movement. They were somewhat more radical than the English legislation of that time, were distinctly amateurish and breeders of disputes over words rather than realities. They have been a cause

49 Fairchild \& Springer, op. cit. supra note 3 , at 570 . 
for reform and not a solvent. By way of terrible example they have been one of the strongest arguments against statutory reform. The special course devoted to them at the Columbia Law School was long known as "Doctrines Peculiar." They may have contributed some progressive elements to the present law of land in the United States but they have not added to its coherence.

No general movement for title registration seems to exist in the United States. The present movement seems local to New York and to have been due not so much to the failure of title insurance as to the failure of the title insurance companies because of their loans. However, the fact that a distinguished governor ${ }^{50}$ could recommend title registration, and that, after a most devastating report, ${ }^{5 \mathrm{I}}$ some at least of its advocates ${ }^{52}$ remained not only unconvinced but still militant, would seem to make the matter one of more than local interest.

Some fourteen years ago, in making a study of property reform in England, ${ }^{53}$ the writer became interested in title registration. Struck by the inefficacy of voluntary registration there, he secured the unprinted report of the Iowa Commission on Land Titles of I923-4. Nineteen states at that time had title registration acts. ${ }^{54}$ In fourteen of these states the use of title registration, if not negligible, had been insignificant. ${ }^{55}$ In the remaining five it had apparently gained a permanent foothold-in Boston, Chicago, Cleveland, Los Angeles, and Minneapolis. ${ }^{6}$ Professor Powell's study ${ }^{57}$ has afforded a check-up for the intervening period. During this time, no state has adopted a Torrens Act. ${ }^{88}$ Four have repealed theirs. ${ }^{59}$ In the remaining ten of the fourteen states the insignificance of the new system had become, if anything, more pronounced.$^{60}$ In two of the five cities where the new system had seemed to gain a permanent foothold (Cleveland and Los Angeles) ${ }^{6 x}$ that foothold had been lost. In Cleveland

$5^{\circ}$ Lehman; see Powell, op. cit. supra note 2 , at 9 .

5 Powell, op. cit. supra note 2.

52 McDougal \& Brabner-Smith, op. cit. supra note 3; Fairchild \& Springer, op. cit. supra note 3 .

53 Bordwell, Property Reform in England, II Iowa L. Rev. I (I925).

34 Bordwell, Registration of Title to Land, I2 Iowa L. Rev. II 5 n. Io, I26 (I927).

35 Ibid., at I26-30.

57 Powell, op. cit. supra note 2.

$5^{6}$ Tbid., at $130-4$.

${ }^{8} 8$ Powell, op. cit. supra note 2 , at 54-6.

59 Powell, op. cit. supra note 2, at 54-5. These states are Mississippi, South Carolina, Tennessee, and Utah.

${ }^{60}$ As to Colorado, Georgia, Nebraska, North Carolina, North Dakota, Oregon, South Dakota, Virginia, and Washington, see ibid., at 55. As to New York, see ibid., at 53.

6x Bordwell, op. cit. supra note 54 , at I26, I30-1, I34. 
there had been no new registrations since $1929,{ }^{62}$ nor in Los Angeles County since $1933{ }^{63}$ Only in Boston, ${ }^{64}$ Chicago, ${ }^{65}$ and the twin cities of Minneapolis and St. Paul ${ }^{66}$ had title registration held its own. In these cities it gave no evidence of ever displacing registration of deeds or even of becoming the prevalent system. ${ }^{67}$ These facts speak for themselves. Voluntary registration of title has been almost as much a failure in the United States as it was in England until under the stimulus of compulsory registration in the County of London, the neighboring counties apparently saw the handwriting on the wall and resorted more freely to the voluntary register. ${ }^{68}$

The failure of the voluntary Torrens System in the United States up to this time, as evidenced by its disuse, does not seem to be seriously questioned by Professor Powell's critics. Fairchild and Springer ask: If compulsion has made title registration work in England, why should it not do the same in the United States?" McDougal and Brabner-Smith say: "Indeed, the chief merit in Professor Powell's book is in its unwitting demonstration, by the data on non-use, of the great need either to make registration compulsory or to provide a mode of voluntary initial registration so

62 Powell, op. cit. supra note 2, at 6r, 244.

${ }_{63}$ Powell, op. cit. supra note 2, at Ioo n. 36. The figures are for the three years 1934-7.

64 Powell, op. cit. supra note 2 , at 6I, $184-6$.

65 Powell, op. cit. supra note 2, at 60-r, 143-8.

${ }^{66}$ Powell, op. cit. supra note 2, at 6r, 206-ro.

${ }_{67}$ In Cook County there has been no apparent increase in the extent or value of registered land since the report of the Iowa Commission in r923-4. See Powell, op. cit. supra note 2, at $\mathrm{I}_{44}-8$. In Boston as early as $\mathrm{I}_{9} \mathrm{I} 3$ there were 49,272 unregistered entires as against 5,636 registered entries so that about ten per cent of the business of Suffolk County had been shifted to the new system and it was predicted that in ten years the amount would be not less than twenty-five per cent. But instead of this, in 1922 it had fallen off to about $7 \frac{1}{2}$ per cent. Bordwell, op. cit. supra note 54 , at $\mathrm{r}_{32}$. In $\mathrm{r}_{93} 6$ the pendulum had swung back and there were $46,38 \mathrm{r}$ non-registered entries as against 7,398 registered entries (Powell, op. cit. supra note 2 , at $184 \mathrm{n} .5 \mathrm{I}$ ) or between thirteen and fourteen per cent of the whole but still only a gain of from three to four per cent over I9r3. In Minneapolis, for I919-36, 10.3 per cent of all instruments affected registered land (ibid. at $207 \mathrm{n}$. 57), a percentage slightly less than that of Boston for 1936. In St. Paul, for the period from 1924 to October I, x937, registration of 27.2 per cent of the transfers indicates the highest percentage of registered land of any of the metropolitan centers. Ibid, at n. 58. However, from 1928 to r936 in both Minneapolis and St. Paul neither system seems to have gained on the other. Ibid., at 210-12. In all three metropolitan centers, therefore, the lines between registered and non-registered land seem to be more or less definitely drawn with little prospect of any great change except through legislation. Two types of registration in one community might be justified temporarily but hardly as a practically permanent arrangement.

68 See supra, p. 474 .

69 Op. cit. supra note 3 , at 576 . Mr. Fairchild is said to be the draftsman of the Phelps-Feld bills looking toward compulsory registration in New York City. The role of London in the English experience is here being assigned to New York. Powell, op. cit. supra note 2, at $76-7$. 
cheap that no opposition can preclude its public acceptance."70 It has been by means of a subsidy that the Torrens System has won such success as it has had in the Twin Cities ${ }^{7 x}$ and also, it would seem, in Chicago. ${ }^{72}$ If a subsidy is required to gain acceptance for the voluntary system and is justified because of the general good, why waste further time with the voluntary system instead of using the amount of the subsidy, if necessary, for the establishment of the compulsory system with its greater promise of success? The argument that would justify the subsidy would justify the compulsion except for extremists of the old Liberal school of thought. Such extremists no doubt still exist and would perhaps raise the question of the constitutionality of compulsory registration of title. But can there be any serious doubt that legislatures can change the method of land transfer if they wish to? To ask the question is to answer it.

If voluntary title registration be rejected as impractical and compulsory registration be accepted as constitutional the question still remains: "Why all this fuss about title registration?" The introduction of the issue into the New York situation seems to have been entirely gratuitous. There had been no such conspicuous failure of the recording system there or even of title insurance as to discredit either. Title insurance had been profitable, perhaps too much so, but the title insurance companies had been allowed to do a banking business as well and banks everywhere went down in the depression. The moral would seem to be to separate title insurance from banking. That moral was immediately accepted ${ }^{73}$ but in some way title registration was lugged in. ${ }^{74}$ Elsewhere the failure of voluntary registration shows that there is no such dissatisfaction with the recording system as to cause a demand for something else. Perhaps this is because the public does not know, but if so, there will have to be a long and intensive educational campaign before compulsory registration of title is accepted.

${ }^{70}$ McDougal \& Brabner-Smith, op. cit. supra note 3 , at Ir49.

${ }^{71}$ In the three counties in which Minneapolis, St. Paul, and Duluth are situated the examiners' fees are paid by the county but not elsewhere in the state. Bordwell, op. cit. supra note 54, at I32-3; see also Powell, op. cit. supra note 2, at 206 n. 56, and 218 n. 64 .

72 In Illinois the examiner's fee is fixed by statute at a price often far less than would be charged by a private examiner and, it is said, at a loss to the county. Powell, op. cit. supra note 2 , at 156 . The county also supplies a "real estate inspector" and thus saves the applicant the cost of a survey. Ibid. Against the loss in the creation of a title plant is set off its probable profit when completed. Ibid., at $15^{8} \mathrm{n}$. 127 .

73 See Powell, op. cit. supra note 2, at 8 . By the Insurance Law, in effect January I, r940, the power of title insurance companies to guarantee mortgages is denied. $\$ \S 432,436,439$.

74 Most of the bills presented in the New York legislature were the outcome of WPA Project No. 6ror. Powell, op. cit. supra note 2, at $76-7$. A great many studies were made but they are not readily available. 
In such an educational campaign as that suggested, the burden of proof in normal times would be on those urging the change. It is commonly argued in support of title registration that, after the initial transfer, there will be cheaper and more expeditious transfers, greater liquidity and utilization of land, and greater security of credits. None of these merits has been so obvious in Boston, Chicago, and the Twin Cities, where title registration must by this time be well known, as to cause any great rush to the register. Greater liquidity and utilization and security would seemingly add so much to the value of the land that in those cities a far-seeing realty operator would not hesitate a minute in making the transfer and soon the idea would become known that land was more valuable registered than unregistered. But no such idea appears to prevail. Land is not as liquid as a share of stock and never will be. It is essentially a local commodity. If greater utilization and security were needed, the need would be felt most in places like the Chicago Loop where skyscrapers abound and mortgages are heavy. But we are told that the land in the Loop is not registered..$^{75}$ If the land market is right, land is liquid provided the title is marketable or the land is not tied up in settlement. If the land market is not right, no register will make the land liquid nor will the register make a non-marketable title marketable except in much the same way as an action to quiet title will make it marketable. Settled land is a question by itself. It can be made alienable without a register if this be desired. Extravagant claims of this kind made for the register are a reflection of the greater fight made for free trade in land in England. The claims for the register there are much more modest in recent years. No millenium will be wrought by a register of title. More substantial arguments for registration seem to be its relative cheapness in the long run, the greater rapidity of transfer, and the saving of lost motion.

Much of the talk about the necessity of repeated searches of the title in the United States is lifted bodily from the English experience and has no proper application here. In parts of England where registration of title does not prevail, all depends upon the preservation of the title deeds and they must be re-examined on each transaction..$^{76}$ The English abstract is a mere guide to the deeds. ${ }^{77}$ The abstract in the United States, however, is an abstract of the record and the search does not normally go behind it. No new abstract is normally required for each new transac-

75 Powell, op. cit. supra note 2, at 148.

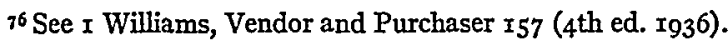

7 Its purpose is "to facilitate the task of judging the effect of the title deeds." Ibid., at I23. However, the purchaser's conveyancing counsel apparently sees only the abstract. Ibid., at 130 . 
tion, but the old abstract is brought down to date. ${ }^{78}$ An abstract once passed upon by a competent lawyer presents little difficulty. Where title insurance prevails and policies are re-issued there is even less lost motion. ${ }^{79}$ The reports of lost motion under the present system are much exaggerated.

Conveyancer, abstracter, and examiner, and even title insurance are accustomed features of the present system, ${ }^{80}$ and these, it is thought, are an unnecessary expense. The need for the abstracter and abstract books arises from the inadequate alphabetical index which is the mark of the official system. Deeds are indexed under grantor and grantee instead of by tracts or by lots and the search under these names is wearisome and unsatisfactory. Many courts have added to the difficulty by charging the purchaser with notice of transactions entered into by a grantor long before he was the record holder and of transactions of his, prior in time but not recorded till long after he ceased being record holder. To supplement the official index, abstract books with tract or lot indexes ${ }^{8 \mathrm{r}}$ have been worked out over the years by private concerns in a great part of the United States. ${ }^{82}$ The person who attempts to make an abstract without such books and from the official records alone is known as a "curbstoner" and, at least in the Middle West, is not in high repute..$^{8_{3}}$

The abstracter is held to a high degree of accuracy ${ }^{84}$ even though his

${ }^{78}$ The distinction between the conveyancer method of assuring title and the abstract opinion method is drawn in Gage, Assuring Agencies in the United States (1937). It is said that the former "has successfully withstood the encroachments of substitute methods in New England, particularly in Boston, and in many of the states along the Atlantic seaboard. In general it may be said to have persisted in those districts of the East and South where the number of land transfers has not been unduly large." Ibid., at 42. The latter is "the prevailing method in Florida, Ohio, Indiana, Michigan, Wisconsin and in all states west of the Mississippi to the Pacific Coast, with the exception of California." Ibid., at 64. Title insurance is given as the prevailing method in Pennsylvania, New Jersey, and California. Ibid., at 156 . The abstract opinion method is marked by the existence of title plants. Ibid., at 44 . "The giving of an abstract" is not peculiar to the abstract-opinion method but "was but a step in the refinement of the conveyancer method of title assuring." Ibid., at 43.

${ }^{79}$ Landels, A Brief Review of the Torrens Experiment in the United States, An Address given at the California Land Title Association, Santa Barbara, California, May 3I, June I and $2,1938, \mathrm{p} .7$.

${ }^{80}$ Note 78 supra.

${ }^{8 x}$ See Gage, op. cit. supra note 78 , at 46 .

82 Note 78 supra.

${ }^{83}$ Jackson, The Curbstoner's Unreliability, 24 Lawyer and Banker 33I (r93x). See also Gage, op. cit. supra note 78 , at $5^{6}$ n. 28.

${ }^{84}$ In Dickle v. Abstract Co., 89 Tenn. 43I, 433, I4 S.W. 896 (I89o) the court said: "To furnish abstracts of titles is a business. Parties undertaking it assume the responsibility of discharging its duties in a skillful and careful manner. Patience in the investigation of records 
liability is usually confined to those in privity of contract with him..$^{85}$ The abstract is not like a covenant which runs with the land. ${ }^{86}$ Furthermore the abstracter may not have the means to make a judgment against him worth anything. If the abstracter is a natural person and not a corporation, his death will further complicate matters. To insure proper responsibility some sort of a bonding arrangement for abstracters seems to be a minimum requirement. ${ }^{87}$ Perhaps more important, however, would be some test of competence insured by the requirement of a license. ${ }^{88}$

The abstracter may or may not be a lawyer. His is the preliminary work of assembling the matters of record affecting the land, not the ultimate task of passing on the marketability of the title. That is a task for a competent lawyer, for whether the title is marketable or not depends upon whether a court would force it on an unwilling purchaser, and predicting what courts will do requires skill and judgment of a high order. Provided he shows the proper skill the lawyer cannot be held to account because his prediction fails to materialize ${ }^{89}$ and the court holds the title unmarketable. To be on the safe side, however, the lawyer is likely to be somewhat conservative and to refuse to approve a title which he himself as a judge might hold good. The marketability of a title is not a matter of mathematical certainty.

The risk that a title may not turn out to be marketable has led to title insurance. This is an extension of the protection given the pur-

is the main capacity required. There is no professional opinion. The agent has only to furnish the facts from the Register's office, without concern for their legal effect. Upon the facts furnished, the purchaser must determine for himself on their sufficiency. The abstract company collects the evidence, and for such collection it is entitled to its fee. If it makes a mistake or oversight, as in this case, it must respond to the injured party." See also Wacek v. Frink, 5 I Minn. 282, 284, 53 N.W. 633 (I892).

8s White, Legal Liability of Abstracters and Title Companies, 9 Title News, No. 10, at 5, 6 (1930). But "most, if not all, states which have bonded abstracters have by statute abolished the rule requiring privity of contract." Ibid.

${ }^{86}$ Phillips, Liability of Abstracters, 5 Title News, No. 8, at 4,8 (Ig26), predicts that eventually it will become settled that if the abstracter's certificate recites that it is for the benefit of the person relying thereon, the latter "may have relief under the doctrine of a contract made for the benefit of third persons" and that in the absence of such a recital the courts will take judicial notice of the custom in the United States that the abstract is prepared for third persons as well as for the owner and that "a primary obligation from the very nature of the work will be held to be created between the abstracter and such third person."

${ }^{87}$ In 1937 , there were bonding laws in eleven states. Gage, op. cit. supra note 77, at 53 .

88 Gage, op. cit. supra note 78 , at $55-6$.

89 For the liability of an attorney passing defective title, see 5 A.L.R. 1389 (I920); Citizens Loan Fund \& Savings Ass'n of Bloomington v. Friedley, I23 Ind. I43, 23 N.E. Io75 (1889). 
chaser by the covenants for title included in the ordinary warranty deed. The warranty commonly gives no protection for subsequent improvements or the increased value of the land $^{90}$ and the warrantor may not be financially responsible. If the warrantor is an established corporation the latter difficulty may not be so great but the limited liability still remains. Title insurance has consequently had a considerable vogue ${ }^{9 x}$ especially in metropolitan centers. ${ }^{92}$ There, improvements loom large and the risk of unmarketable title may well be covered as an incident of business. In rural sections, it seems that title insurance has as yet largely to make its way ${ }^{93}$ although statistics are inadequate..$^{94}$ In some respects title insurance seems to have lost ground. Writing in 1937, Professor Gage expressed the opinion that it had reached its zenith in I930.95 Doubtless the depression and the failure of outstanding title insurance companies had much to do with this. At that time it is said to have been universally available through the New York Title and Mortgage Company which offered to underwrite title risks anywhere in the United States. ${ }^{96}$ On the reorganization of that company, however, its nationwide business was dropped"7 and it seems to be accepted that "title insurance is inherently a local business." ${ }^{98}$ It may be state-wide and even go beyond state lines ${ }^{99}$ but like the land which it concerns it is essentially a local commodity. In about a quarter of the states there seem to be no local companies. ${ }^{\mathbf{x} 0}$ Where the title insurance company is strictly local, as in the large cities, it may well combine the work of abstracter, attorney, and insurer and thus effect economies; but where this is not the case, title insurance would seem to be just an added item to the expense of land transfer.

Perhaps the most obvious criticism of the existing order is the inadequate official index. If the official alphabetical index is inadequate why not get one that is adequate? Private enterprise has supplemented the

${ }^{\circ}$ See Davis v. Smith, 5 Ga. 274 (I848); Handler, Cases on Vendor and Purchaser 7 Io and 714 n. 92 (I933).

${ }^{9 x}$ It was statewide in only California, New Jersey, and Pennsylvania. Gage, op. cit. supra note 78 , at 156 .

${ }_{92}$ These metropolitan centers are scattered throughout the United States. Tbid.

93 Notwithstanding the ascription of state-wide title insurance to Pennsylvania (note $9 \mathrm{I}$ supra) all that Umsted, of Philadelphia, could say in I930 was "the smaller towns are taking up title insurance." ro Title News, No. I, at 53 (1930).

94 See Gage, op. cit. supra note 78, at $85 . \quad 96 \mathrm{Gage,} \mathrm{op.} \mathrm{cit.} \mathrm{supra} \mathrm{note} 78$, at 85 , Ir9.

95 Gage, op. cit. supra note 78 , at $85 . \quad 97$ Gage, op. cit. supra note 78 , at 120 .

${ }^{8}$ Note 78 , at r2o. Gage, op. cit. supra note 78 , at 120 .

${ }^{99}$ Gage, op. cit. supra note 78 , at $120 . \quad{ }^{100}$ Gage, op. cit. supra note 78 , at 85 n. 24. 
official index with its abstract books but why not take over this private enterprise? This would be merely an attempt to better what is now being done badly by the government, not a departure into new fields. A very considerable profession, that of the private abstracter, would be eliminated, but such eliminations are often the price of progress. Many of the abstracters no doubt would find employment in the public service and some of the existing abstract books would have to be purchased. It would be sheer waste for the government to duplicate abstract books where there are already adequate ones in existence. There would thus be considerable expense in starting the new official index and no doubt considerable added expense in keeping it up to date, but the cost of the abstract to the purchaser would largely be eliminated although some of this expense would be thrown on the state. There would be the further advantage that public officials are bonded and so responsibility is ensured.

Aside from the heartburnings incident to the elimination of an honorable profession, the objection has been urged that better officials are needed to make the change a success. The alphabetical index is fairly mechanical. The making of an abstract book or tract index, it is urged, is another matter. Nothing like the same skill would be required, however, as is required in passing on the marketability of the title. The latter would still be work for a competent laywer. And title insurance would still have its place, though any monopoly based on possession of abstract books would be avoided.

Advocates of title registration have claimed the official tract index as a species of title registration. ${ }^{\text {ror }}$ Statistics and statements as to title registration should be read with this in mind. So defined, title registration is certainly not revolutionary. But it is a far cry from the Torrens System and it is with the Torrens System or something very much like it that title registration is identified in the United States. Were the tract index adopted, an unofficial index would be made official and that would be all. The general land law would not be affected.

As distinguished from mere tract indexing, title registration proper, excluding the registration of possessory titles, involves a determination of title. The proceeding is much like the statutory proceeding to quiet

sos Hogg, Registration of Title to Land throughout the Empire I (rg20): "By deed registration-or registration of deeds-is meant primarily a system under which instruments are recorded merely as such, and not with special reference to the land they purport to affect. By title registration -or registration of title-is meant primarily a system under which a record is made of the title to some particular land as vested in some particular person for the time being, or of instruments as affecting some particular land." McDougal \& Brabner-Smith, . op. cit. supra note 3 , at II 26 n. 5, II30, II49, apparently use title registration in the same sense. 
title to be found especially in the western states. ${ }^{\text {xoz }}$ The choice between registration of title and the action to quiet title is likely to depend on their relative cheapness. ${ }^{\mathrm{I03}}$ The need of some more adequate method of trying title to land than the old action of ejectment is evident. It was not open to the one in possession and years might pass before the one in possession was given the opportunity to test his title in court. The result, when one did get into court, might be res judicata between the parties ${ }^{\text {To4 }}$ but the parties were limited in number ${ }^{\mathrm{ros}}$ and the world at large was unaffected. In the statutory action to quiet title, the one to bring the action is normally the one in possession and the parties to the action are made so inclusive as to give it nearly, if not quite, the effect of an action binding the whole world..$^{\text {ro6 }}$ The desirability of some such proceeding is manifest. Once title is quieted there will be little trouble about its further marketability. It is one thing, however, to be forced into such a proceeding by a compulsory registration statute and another to enter upon it voluntarily. If there is compulsion the state ought to bear much of the expense, while if the proceeding is voluntary the expense should be met as in any other voluntary litigation.

The arguments for an adequate official index to the Register and for a comprehensive action to quiet title are therefore very strong. To the writer it would seem that these should be tried before anything more revolutionary is attempted. The tendency to look to foreign models is not always a desirable one. To change the figure, other people's pastures are likely to look greener than ours, but the greenness is often an illusion. The Torrens System is a foreign system, admirable no doubt in its time and place, but uncalled for in the United States. The agitation for it in New York would seem a passing phase of politics. ${ }^{x 07}$

${ }^{202}$ Pomeroy, Code Remedies $\$ 266$ (5th ed. x929).

${ }^{103}$ See Powell, op. cit. supra note 2, at 62, and 206 n. 56.

ro4 See Sedgwick \& Wait, Trial of Title to Land $\$ \S 43-4$ (2d ed. I886).

sos Ibid., at $\S \S 260-r$.

${ }^{106}$ Pomeroy, Code Remedies $\$ 266$ (5th ed. 1929 ).

${ }^{107}$ Many of the phases of Title Registration are here untouched. One of these is the conclusiveness of the certificate. Another is the favor shown to the purchaser. Another is the tendency to shift burdens, hitherto considered private, onto the public. Regardless of the conclusiveness of the certificate, of the desirability of cutting off stale claims and of the modern tendency to look to the state, the case for the adoption of the Torrens System in the United States does not seem to be made out. 